\title{
Improvement of methodological aspects to calculate the cost of dairy products: a review
}

\author{
$B$ Menglikulov ${ }^{1, *}, R$ Dusmuratov ${ }^{1}$, and $D$ Mamadiyorov $^{1}$ \\ ${ }^{1}$ Tashkent State Agrarian University, University str., 2, Tashkent province, Uzbekistan, 100140
}

\begin{abstract}
This article deals with the calculation of the cost of products in dairy farming. The approaches of economists to the concepts of cost and calculation have been studied. Conclusions, scientific proposals and practical recommendations have been developed to improve the methodological aspects of costing in dairy farming.
\end{abstract}

\section{Introduction}

One of the most important issues today is the organization of cost accounting and control in accordance with market requirements. In animal husbandry, it is important to correctly formulate costs, accurately calculate the cost and reflect it in the accounting records in a timely manner [1, 2-5].

In the cultivation of livestock products, a large part of the cost is spent on feed. The fact that the bulk of fodder is not covered by local resources, leads to increased costs and high costs [6-8]. It is known that it is important to form the cost and its theoretical basis in accordance with the requirements of regulatory documents. For this reason, in practice in our country there are normative and legal acts regulating expenditures [9-14].

Such documents include the Regulation "On the structure of costs of production and sale of goods (works, services) and the order of formation of financial results", approved by the Cabinet of Ministers of the Republic of Uzbekistan dated February 5, 1999 No 54 [1]. In modern theory, the concept of costs has some aspects that differ from the concept of costs reflected in the accounting of the activities of the business entity [15-17]. Because in accounting, expenses are formed on the basis of the methods, principles and officially established requirements of the discipline. The issue of objective formation of economic data on costs in the activities of economic entities is carried out through accounting and its methods.

\subsection{Review on the term 'expenditure'}

The concept of expenditure is broader than the concept of cost and calculation. Expenditures are a monetary expression of the costs and expenses incurred by an entity to achieve its objectives and to address the objectives it has set for itself.

*Corresponding author: b.y.menglikulov@yandex.com 
Based on the above considerations, it will be necessary to clearly define the essence of the concept of "expenditure". Therefore, we consider the approaches of economists to costs (Table 1).

Table 1. Basic definitions and approaches to the content of the concept of "expenditure" given by economists.

\begin{tabular}{|c|c|}
\hline Source of information & Definitions and approaches to the concept of expenditure \\
\hline $\begin{array}{c}\text { National Encyclopedia of } \\
\text { Uzbekistan [2] }\end{array}$ & $\begin{array}{c}\text { Expenditure - a monetary expression of the costs associated with } \\
\text { the consumption of various resources (raw materials, supplies, } \\
\text { labor, services, funds) in the production and handling of goods }\end{array}$ \\
\hline K. Urazov [3] & $\begin{array}{c}\text { Expenditure is defined as a decrease in an entity's assets or an } \\
\text { increase in liabilities during the reporting period }\end{array}$ \\
\hline A. Ibragimov et al. [4] & $\begin{array}{c}\text { Expenditure is the cost of acquiring material resources and, } \\
\text { according to the concept of income and expenses, should bring } \\
\text { income in the same period. }\end{array}$ \\
\hline A. Karimov et al. [5] & $\begin{array}{c}\text { Expenditure is the occurrence of liabilities that result in a } \\
\text { decrease in economic benefits in the reporting period in the form } \\
\text { of an outflow of assets or their use. }\end{array}$ \\
\hline B. Ruzmetov et al. [6] & $\begin{array}{c}\text { Expenditure is the costs incurred in producing goods and } \\
\text { providing services. }\end{array}$ \\
\hline B. Khasanov et al. [7] & $\begin{array}{c}\text { Expenditure is the monetary expression of the costs associated } \\
\text { with the production of goods, the sale of goods, the performance } \\
\text { of work and the provision of services. }\end{array}$ \\
\hline S. Tashnazarov [8] & $\begin{array}{c}\text { Expenditure is a monetary expression of the value of resources } \\
\text { expended to achieve the intended purpose (production of goods, } \\
\text { purchase of goods, services). }\end{array}$ \\
\hline L. Shalaeva [9] & $\begin{array}{c}\text { "Expenditure is a set of economic resources of economic entities, } \\
\text { formed and transformed in the course of their activities and } \\
\text { manifested in the form of the organization." }\end{array}$ \\
\hline N. Noskova [10] & $\begin{array}{c}\text { Expenditure is the value of the resources an enterprise uses in the } \\
\text { course of its operations. }\end{array}$ \\
\hline
\end{tabular}

Recognizing the definitions and approaches of the above economists, the author's approach to the concept of "expenditure" was formed as follows: "Expenditure is a monetary expression of material, labor and other costs in the production of goods and services to achieve the goals of the business entity."

In the general system of indicators reflecting the efficiency of production activities in the business entity and its individual divisions, the cost indicator plays a key role. Because the cost structure consists of the sum of the corresponding costs that make it up.

\subsection{Review on the term 'cost'}

Cost is the value of creating product value through the production of goods, the performance of work and the provision of services. Cost calculation is of great importance in assessing the scientific validity of cost norms and standards, monitoring their dynamics and identifying cost reduction reserves, as well as in determining the market price of products and its rapid revision. Therefore, it is necessary to scientifically substantiate the concept of cost and product cost (Table 2).

After studying the definitions and approaches of economists in the source on the concept of "cost", the following author's approach was developed: "Cost is a monetary expression of the total current costs incurred for a unit of product, work performed and services rendered." 
Table 2. Basic approaches to the concept of "cost" in the economic literature.

\begin{tabular}{|c|c|}
\hline Source of information & Definitions and approaches to the concept of cost \\
\hline $\begin{array}{l}\text { National Encyclopedia of } \\
\text { Uzbekistan [2] }\end{array}$ & $\begin{array}{l}\text { Cost, cost of goods sold - is a monetary expression of the total } \\
\text { current costs incurred by the enterprise for the production and } \\
\text { sale of goods and the performance of work or provision of } \\
\text { services. }\end{array}$ \\
\hline $\begin{array}{l}\text { R. Dusmuratov and B. } \\
\text { Menglikulov [11] }\end{array}$ & $\begin{array}{c}\text { Cost is an important economic indicator of economic production } \\
\text { and financial activity. }\end{array}$ \\
\hline N. Noskova [10] & $\begin{array}{l}\text { "Cost is a type of expense that is allowed to reduce (i.e., deduct } \\
\text { from income) financial results in accordance with the standards } \\
\text { and principles of financial reporting in each specific situation. }\end{array}$ \\
\hline V. Kerimov [12] & $\begin{array}{l}\text { The cost of a product is the total monetary cost of the enterprise, } \\
\text { which is based on the operating costs of production in the } \\
\text { production and sale of the product. }\end{array}$ \\
\hline $\begin{array}{l}\text { A. Makhkambaev et al. } \\
{[13]}\end{array}$ & $\begin{array}{l}\text { The cost of a product is a monetary expression of the total costs } \\
\text { incurred by the enterprise to produce and sell the product, which } \\
\text { is based on the operating costs of production. }\end{array}$ \\
\hline
\end{tabular}

\subsection{Review on the term 'calculation'}

In a free economy, the essence of calculation is determined by the need to have clear production conditions, cost indicators for cost comparison, pricing, control and decisionmaking, and the use of costing methods for the stated purposes. The essence of the calculation is given in different definitions and approaches in the economic literature (Table 3).

Table 3. Definitions and approaches to the content of the concept of "calculation" in dictionaries and economic literature.

\begin{tabular}{|c|c|}
\hline Source of information & Definitions and approaches to the concept of cost \\
\hline $\begin{array}{c}\text { National Encyclopedia of } \\
\text { Uzbekistan [2] }\end{array}$ & $\begin{array}{c}\text { Calculation (lat. Calculatio, calculo - calculate, calculate) - the } \\
\text { calculation of the unit of production or the cost of work } \\
\text { performed. }\end{array}$ \\
\hline $\begin{array}{c}\text { A. Makhkambaev et al. } \\
{[13]}\end{array}$ & $\begin{array}{c}\text { Calculation is a method of calculating the cost of a unit of } \\
\text { product (work, services) (sum of the calculation process). }\end{array}$ \\
\hline R. Dusmuratov [14] & $\begin{array}{c}\text { Costing is the determination of the cost of materials produced, } \\
\text { products produced, work performed and services rendered. }\end{array}$ \\
\hline B. Ruzmetov et al. [6] & $\begin{array}{c}\text { Costing is the calculation of costs per unit of output for a } \\
\text { particular type of product or work performed in monetary terms. }\end{array}$ \\
\hline N. Noskova [10] & $\begin{array}{c}\text { A calculation is a list of costs that an enterprise needs to produce } \\
\text { a particular type of product, or to perform a particular activity of } \\
\text { an enterprise. }\end{array}$ \\
\hline
\end{tabular}

Based on a study of the definitions and approaches of economists cited in the data source, the following authorial approach of the researcher was formed. "Calculation is a method of calculating the cost of a unit of product (work, service)."

The cost and cost of production of livestock products reflects the impact of all factors of production and financial and economic activities, ie the efficient use of material, labor, biological and financial resources. These factors are most reflected in the cost of dairy products. For example, the cost of milk for dairy farming indicates how much the production and sale of this product will cost the agricultural enterprise. The profitability of production and sale of products in agricultural enterprises depends on the cost of dairy products. 
Therefore, in the system of internal management of dairy farming, first of all, its main functions: in this subsystem of animal husbandry it is necessary to solve the problem of information support of production planning and its cost planning, control and analysis. In dairy farming, the system of cost management management accounting and product costing (calculation) should be the main information base for the effective management of material, biological, labor and financial resources. This system should meet the information needs of internal management in the implementation of objective standardization, planning, control and analysis of livestock production costs, output and production results in agricultural enterprises $[16,17,20]$.

\section{Calculating the cost of dairy products}

In the system of internal management of agricultural enterprises it is important to calculate the cost of dairy products on a scientific basis. Economic dictionaries define the cost of products as follows: "Calculation - the calculation of the unit cost of a product (service) by type of cost (calculation items)" [18]. There are more clear definitions of this concept in the economic literature: "Product costing is the grouping of costs and the determination of the cost of finished products by the cost items associated with its production and sale" [19].

It should be noted that the calculation is also one of the elements of the accounting method, such as valuation, that is, the method of calculating the cost of the product. Calculation is also a separate independent stage of economic work on the calculation and analysis of the cost of the product [20]. In this case, the cost of the product is the monetary cost of labor, material, biological and financial resources used in its production and sale [21]. Therefore, the organization of accounting for production costs in dairy farming and the validity of the calculation of the cost of production is of great importance for determining the optimal selling price for milk, the correct financial results from the sale of these products and more profitable channels of their sale.

Correct determination of calculations, calculation units and calculation periods in each farm for objective calculation of the cost of products in dairy farming; use of alternative methods of estimating the cost of material and biological costs included in the cost of dairy products; formation of an effective control mechanism for operational verification of full accounting of costs and output in animal husbandry; it is necessary to develop and put into practice reasonable methods of calculating the cost of products in dairy farming $[22,23$, 24].

In modern conditions, the discussion of the problem of calculating the cost of products, the list of objects of calculation, units of calculation and timing of the calculation of cost is common in the work of many authors [24].

Taking into account all the organizational-technological, agrobiological, managerial and other characteristics and conditions of operation of dairy farms, it was determined that the objects of cost calculation in this subsystem of animal husbandry may be: dairy cows, types of products (milk, offspring). The units of calculation in dairy farming are: one head of dairy cow, one head of offspring and 1 quantile (q) of milk. Dairy farming can have a specific period (winter, summer, autumn) or a reporting year.

At the end of each specific period of the year to calculate the cost of basic and additional products, the cost of materials and biological means of labor in dairy farming (cost of past periods) or the cost of the planned cost (feed, livestock protection, etc.) In animal husbandry, it will be necessary to move to real value valuation [21]. In addition, effective control over production costs and product output should be established during the herd life cycle or productive use period of dairy cows.

In the modern conditions of development of the agrarian economy, it is necessary to decide on the basis of the main part of the sum of production costs in dairy farming (minus 
the value of additional products) based on the main (milk) and additional (offspring) products. Currently, the method of distribution of milk production $(90 \%)$ and reproduction $(10 \%)$ based on energy exchange of feeds is used to calculate the cost of products in dairy farming. In modern conditions, when this method is used, the cost of dairy products becomes conditional, which leads to more unreliable, non-objective cost indicators (for example, the cost of breeding is very high). Therefore, it is necessary to use other more reasonable methods of calculating the cost of products in dairy farming.

It is known that in dairy farming the main milk yield is $1 \mathrm{q}$ per cow. the cost of milk and one head of offspring is determined by deducting the cost of keeping dairy cows and bulls, the cost of other products: $1 \mathrm{q}$ manure and wool according to the method of determining the cost of production in dairy farming, selected in the accounting policy of the enterprise on the remaining costs after deduction of the cost of manure, wool and wool from the total costs of dairy farming. The cost of milk and one head of offspring is determined.

In order to deduct the cost of by-products (manure, wool and wool) from the total cost, they are valued at a fixed price: manure - the purchase of mineral fertilizers, taking into account the presence of nutrients (active substances of mineral fertilizers - nitrogen, phosphorus, potassium) at a price, wool and wool - at a price that can be sold or used [18]. Manure on farms can also be estimated based on the normative costs of collecting it under certain conditions and the value of the bedding under the cattle. The normative (calculated) cost of manure collection consists of the cost of obtaining them from the manure collection points and storing them on technological cards and depreciation costs calculated on the fixed assets used in their removal from the manure storage area. The cost of 1 ton of manure is determined by dividing the total cost by its mass.

The cost of $1 \mathrm{q}$ milk is calculated by dividing the sum of the costs of its production by the physical mass of the milk obtained, and the cost of one head is calculated by dividing the cost of production by the number of offspring obtained. In this case, it is recommended to use one of the following methods given in sub-sections below in the distribution of the amount of costs after deducting the cost of manure, wool and wool from the total cost of dairy farming.

\section{Calculation methods of the cost of dairy products}

\subsection{Captions/numbering}

Its essence is that the remaining amount to be paid for milk and offspring (after deduction of products from the total cost) is distributed in proportion to the average selling price of each product of milk and offspring, i.e. $1 \mathrm{q}$ milk is valued at the selling price, the total obtained offspring is $1 \mathrm{q}$ of this breed on the farm. is estimated at the selling price of live weight or $1 \mathrm{q}$ consists of the distribution of the selling price (Table 4).

Table 4 shows that $98.5 \%$ or $1,811,366,000$ UZS were transferred to milk $(1,838,950 \mathrm{x}$ $0.985)$ and $1.5 \%$ or $27,584,000$ UZS $(1,838,950 \times 0.015)$ to the offspring after deducting the value of the approach products $(1,838,950,000$ UZS). Based on the data obtained in column 6 of Table 1, we determine the cost:

1 q milk - 349,347 UZS $(1,811,366,000: 5,185)$;

One head count of generation - 1,532,444 UZS $(27,584,000: 18)$;

1 q live weight of one head generation - $\mathbf{3 , 0 6 4 , 8 8 9}$ UZS $(27,584,000: 9)$. 
Table 4. Proportional calculation of the cost of basic livestock products in dairy farming

\begin{tabular}{|c|c|c|c|c|c|}
\hline \multirow{2}{*}{ Indicators } & \multirow{2}{*}{$\begin{array}{l}\text { Quantity } \\
\text { (unit of } \\
\text { measure) }\end{array}$} & \multicolumn{2}{|c|}{$\begin{array}{c}\text { Basic and approach } \\
\text { product value }\end{array}$} & \multirow{2}{*}{$\begin{array}{l}\text { Production } \\
\text { costs, }{ }^{6000} \\
\text { UZS }\end{array}$} & \multirow{2}{*}{$\begin{array}{c}\text { Cost of } 1 \mathrm{q} \\
\text { milk and } \\
\text { offspring live } \\
\text { weight, UZS }\end{array}$} \\
\hline & & '000 UZS & $\begin{array}{c}\% \text { of the } \\
\text { total }\end{array}$ & & \\
\hline 1 & 2 & 3 & 4 & 5 & 6 \\
\hline $\begin{array}{l}\text { 1. Number of } \\
\text { livestock on the } \\
\text { farm, head }\end{array}$ & 385 & - & - & - & - \\
\hline $\begin{array}{c}\text { of which: number of } \\
\text { cows, head }\end{array}$ & 173 & - & - & - & - \\
\hline $\begin{array}{l}2 . \text { The main } \\
\text { production costs of } \\
\text { dairy farming - total, } \\
\text { ' } 000 \mathrm{UZS}\end{array}$ & - & - & - & 1,846 & - \\
\hline \multicolumn{6}{|l|}{$\begin{array}{l}\text { 3. Taken throughout } \\
\text { the year: }\end{array}$} \\
\hline a) milk, q & 5,185 & 1,897 & 98.5 & 1,811 & $349,347.0$ \\
\hline \multicolumn{6}{|l|}{ b) generation: } \\
\hline Head & 18 & - & - & - & $1,532,444.0$ \\
\hline live weight, $\mathrm{q}$ & 9 & 28.8 & 1.5 & 27.5 & $3,064,889.0$ \\
\hline в) manure, tons & 141 & - & - & - & - \\
\hline $\begin{array}{c}\text { 4. Basic and } \\
\text { approach product } \\
\text { value, total }\end{array}$ & - & 1,926 & 100 & - & - \\
\hline $\begin{array}{l}\text { 5. Production costs } \\
\text { after deducting the } \\
\text { cost of manure in } \\
\text { dairy farming } \\
(1846000000- \\
141 \times 50000)\end{array}$ & - & - & - & 1,838 & - \\
\hline
\end{tabular}

Comment: The cost of 1 ton of manure in the farm - 50,000 UZS

\subsection{Method of deducting the value of additional products}

This method of calculating the cost of dairy products is due to the fact that in this case it is a dairy product and the need to assess the efficiency (profitability, profitability) of its production and sale to make economic decisions in the internal management system (Table 5) $[20]$.

\subsection{Coefficient method}

The essence of this method is that the value of additional products (manure, wool, etc.) is deducted from the total cost of production in dairy farming. The amount obtained is divided by the amount of conditional product equal to milk (equalization coefficients: milk - 1 , offspring - 1.5). The resulting division is the cost of $1 \mathrm{q}$ conditional milk. We determine the cost of 1 head of offspring by multiplying the cost of conditional milk by the coefficient of equation of the offspring to the conditional milk ( $1.5 \mathrm{ha})$.

Let's assume that the annual cost of keeping cows (173 heads) amounted to 1,846,000 UZS, during the year $5,185 \mathrm{q}$ of milk, 18 head of offspring were obtained. The cost of additional products (manure) amounted to 50,000 UZS. Based on this, we determine the following:

a) cost of basic and additional products (milk and breeding): $1,846,000-7,050=$ 


\section{$1,838,950 \mathrm{UZS}$}

b) total amount of milk and offspring (transferred to conditional milk): $5,185+(18 \mathrm{x}$ $1.5)=5,212 \mathrm{q}$;

c) conditional cost of 1 q of milk: $1,838,950: 5,212=352,830 \mathrm{UZS}$;

d) the cost of one head: $521,200 \times 1.5=1,781,800 \mathrm{UZS}$.

Table 5. Calculation of the cost of products in dairy farming by deducting the cost of additional and related products from production costs

\begin{tabular}{|c|c|}
\hline Indicators & $\begin{array}{l}\text { Primary data and } \\
\text { calculated indicators (in } \\
\text { units of measurement) }\end{array}$ \\
\hline 1 & 2 \\
\hline 1. Production costs in dairy farming - total, ' $000 \mathrm{UZS}$ & $1,846,000$ \\
\hline 2. The average annual number of cows, head & 173 \\
\hline $\begin{array}{l}\text { 3. Product output in dairy farming: } \\
\text { a) milk, } \mathrm{q} \\
\text { b) generation: } \\
\text { head } \\
\text { live weight, } \mathrm{q} \\
\text { c) manure, tons }\end{array}$ & $\begin{array}{c}5,185 \\
18 \\
9 \\
141 \\
\end{array}$ \\
\hline $\begin{array}{l}\text { 4. Product value: } \\
\text { a) Live weight of cattle in this breed (smental breed) is } 1 \mathrm{q} \text { the value } \\
\text { of the offspring based on the selling price, '000 UZS } \\
\text { b) the cost of manure, ' } 000 \mathrm{UZS} \text {, based on the nutrient content of } \\
\text { manure and the purchase price of the relevant mineral fertilizers }\end{array}$ & $\begin{array}{r}28,890 \\
1,050 \\
\end{array}$ \\
\hline $\begin{array}{l}\text { 5. Costs of dairy production, minus the cost of seed and manure, ' } 000 \\
\text { UZS }\end{array}$ & $1,811,366$ \\
\hline 6. The cost of $1 \mathrm{q}$ of milk, UZS & 347,997 \\
\hline 7. Value: & \\
\hline a head generation, UZS & $1,618,261$ \\
\hline $1 \mathrm{t}$ of manure, UZS & 50,000 \\
\hline
\end{tabular}

Comment: It is recommended to use the value of one head of seed and 1 ton of manure in the accounting and reporting in estimating the cost of these additional and related products.

\subsection{Method of transportation (distribution)}

To justify the use of this method in practice, depending on the metabolic energy consumption of feed, only the cost of feed for the main and additional product is carried out as follows: $10 \%$ for breeding and $90 \%$ for milk (provided that the reproduction from 100 cows is $100 \%$ ) [15]. In dairy farming, other costs less value added are allocated to milk and offspring in proportion to their selling prices [16].

Thus, the cost of feed for the production of dairy products on the farm amounted to $493,989,000$ UZS. Of this, $92 \%$ is for milk production, or $454,470,000$ UZS $(493,989 \mathrm{x}$ $0.92), 8 \%$ for reproduction, or 39,519,000 UZS (493,989 x 0.08$)$.

Only $8 \%$ of feed costs were spent on breeding (calves), as the breeding rate per 100 cows on this farm was $80 \%$. Then all other costs of dairy production $(1,846,000-493,989=$ $1,352,011,000 \mathrm{UZS}$ ) are distributed to milk and offspring in proportion to their selling prices, minus the value of additional products $(1,352,011-52,426=1,299,585,000 \mathrm{UZS})$. To be clear, the calculation of the cost of $1 \mathrm{q}$ of milk and one head of offspring is given in Table 6.

Let's assume again that the amount of annual costs after deduction of the cost of byproducts (manure) in dairy farming is $1,838,950,000 \mathrm{UZS} .1 \mathrm{~kg}$ of milk (for example, the fat content is $4 \%$ ) contains 3 UZS and 17 UZS per $1 \mathrm{~kg}$ of live weight. During the year, 
$1,555,500$ UZS $(518,500 \times 3)$ of milk converted to metabolic energy and 15,300 UZS (900 $x$ 17) of live weight converted to metabolic energy were obtained. The share of metabolic energy in milk in the total metabolic energy from primary and secondary products (milk and offspring) is $99 \%(1,555,500: 1,570,800 \times 100)$, the share of metabolic energy in live weight of offspring is $1 \%(15,300: 1,570,800 \times 100)$. Using this information, we determine the following:

a) cost of 1 q of milk: $1,838,950,000 \times 0.99: 5,185=351,120 \mathrm{UZS}$;

b) cost per head: $1,838,950,000 \times 0.01: 18=1,021,639$ UZS.

Table 6. Calculation of the cost of products by the method of milk production and transmission to the offspring in proportion to their value on the basis of metabolic energy consumption and other costs (minus the cost of additional products) in dairy farming

\begin{tabular}{|c|c|c|}
\hline Indicators & $\begin{array}{c}\text { Primary } \\
\text { sources }\end{array}$ & $\begin{array}{l}\text { Calculated } \\
\text { data, UZS }\end{array}$ \\
\hline 1 & 2 & 3 \\
\hline 1. The average annual head count of cows & 173 & - \\
\hline $\begin{array}{l}\text { 2. Taken throughout the year: } \\
\text { a) milk, } \mathrm{q} \\
\text { b) generation: } \\
\text { head } \\
\text { live weight, } \mathrm{q}\end{array}$ & $\begin{array}{c}5,185 \\
18 \\
9 \\
\end{array}$ & $\begin{array}{l}- \\
- \\
-\end{array}$ \\
\hline $\begin{array}{l}\text { 3. Feed costs, '000 UZS } \\
\text { From this, conducted: } \\
\text { a) milk - } 92 \% \\
\text { b) offspring - } 8 \% \\
\end{array}$ & $\begin{array}{c}493,989 \\
- \\
-\end{array}$ & $\begin{array}{c}- \\
454,470,000 \\
39,519,000 \\
\end{array}$ \\
\hline $\begin{array}{l}\text { 4. Production costs in dairy farming, minus the cost of feed and } \\
\text { by-products }(1,846,000-493,989-52,426) \text {, '000 UZS } \\
\text { From this, the following was carried out: } \\
\text { a) milk - } 98.5 \% \\
\text { b) offspring }-1.5 \%\end{array}$ & $\begin{array}{c}1,299,585 \\
- \\
-\end{array}$ & $\begin{array}{c}1,280,091 \\
19,494 \\
\end{array}$ \\
\hline $\begin{array}{l}\text { 5. Cost, UZS: } \\
\text { a) } 1 \text { q of milk (row } 3 a+\text { row } 4 a \text { : row } 2 a) \\
\text { b) } 1 \text { head offspring (row } 3 b+\text { row } 4 b \text { : row } 2 b)\end{array}$ & - & $\begin{array}{c}87,898 \\
2,196,583\end{array}$ \\
\hline
\end{tabular}

\section{Discussion}

In order to achieve a reasonable, objective and accurate calculation of the cost of each type of product in dairy farming, it is necessary to organize the completeness of accounting for all types of products in this sub-sector of animal husbandry in agricultural enterprises. We are talking not only about the calculation of milk, offspring and related products, but also about the calculation of the increase in live weight of large horned cattle used. Thus, young cattle (heifers) for repair will increase their live weight due to the increase in each year of productive exploitation during the productive period (period) after transfer to the main dairy herd. This increase in live weight, which is not currently reflected in accounting and zootechnical accounting, leads to incorrect (artificially understated) value of the herd of cattle in the accounting (financial) report and the fact that this part of the value is not depreciated.

The share of costs incurred in increasing the live weight of dairy cows should be deducted from the increase in the live weight value of these livestock. Accordingly, the increase in live weight of dairy cows taken into account for calculation should lead to the increase in live weight of this type of livestock in accounting and zootechnical accounting. 
All this helps to restore the real value and live weight of dairy cows in the agricultural enterprise at the end of each reporting year in the accounting and zootechnical account, in the accounting (financial) report (balance sheet).

In order to achieve a reasonable, objective and accurate calculation of the cost of each type of product in dairy farming, it is necessary to organize the completeness of accounting for all types of products in this sub-sector of animal husbandry in agricultural enterprises. We are talking not only about the calculation of milk, offspring and related products, but also about the calculation of the increase in live weight of large horned cattle used. Thus, young cattle (heifers) for repair will increase their live weight due to the increase in each year of productive exploitation during the productive period (period) after transfer to the main dairy herd. This increase in live weight, which is not currently reflected in accounting and zootechnical accounting, leads to incorrect (artificially understated) value of the herd of cattle in the accounting (financial) report and the fact that this part of the value is not depreciated.

Therefore, at the end of the reporting year, in order to calculate the cost of production, the increase in live weight of dairy herds on farms is determined. Then the value of additional products (manure, wool, etc.) is deducted from the total cost of raising (keeping) a herd of dairy cows. The sum of the remaining costs is the increase in live weight of milk, pedigree and dairy cows in proportion to the market value of each product or the amount of energy exchange for each type of product (3\% fat content per $1 \mathrm{q}$ of milk energy exchange (metabolic energy) - $2.3 \mathrm{Mdj}, 4 \%$ fat content - $3 \mathrm{Mdj}, 5 \%$ fat content - $3.31 \mathrm{Mdj}, 1 \mathrm{~kg}$ live weight of the offspring (calf) - $17 \mathrm{Mdj}, 1 \mathrm{~kg}$ added weight of cattle - $20 \mathrm{Mdj}$ ) [15].

The share of costs incurred in increasing the live weight of dairy cows should be deducted from the increase in the live weight value of these livestock. Accordingly, the increase in live weight of dairy cows taken into account for calculation should lead to the increase in live weight of this type of livestock in accounting and zootechnical accounting. All this helps to restore the real value and live weight of dairy cows in the agricultural enterprise at the end of each reporting year in the accounting and zootechnical account, in the accounting (financial) report (balance sheet).

\section{Conclusions}

An agricultural enterprise can independently select and use any of the above methods of calculating the cost of dairy products. This should be based on the information needs of the internal management of livestock, as well as the need to use the cost of production for:

- Estimation of stocks (milk, offspring) in accounting and reporting;

- Analysis of the cost of milk production and breeding separately, respectively, the cost recovery of these types of products at fair value or domestic transfer prices;

- Evaluation of the efficiency of dairy production;

- substantiation of agrarian policy on milk price formation in the conditions of market competition.

In addition to the above, the choice of one or another method of cost calculation in dairy farming depends on the production (management) accounting model adopted independently in each enterprise, the adopted accounting policy, production and financial strategy of development, as well as the strategic goal of this subdivision. In order to increase the efficiency of production in the system, it should be addressed in the light of the operational, current and tactical tasks set before the livestock management system. 


\section{References}

1. Decree of the Cabinet of Ministers of Uzbekistan No.54 "On the Structure of Production and Sales Costs of Products (works, services) and the Order of Formation of Financial Results", February 5 (1999)

2. National Encyclopedia of Uzbekistan, State Scientific Publications. 392 (2002)

3. K. B. Urazov, Accounting and Audit, 1, 245 (2004)

4. A. Ibragimov, I. Ochilov, I. Kuziev, N. Rizaev, Financial and Managing Calculations, 1, 444 (2008)

5. A. Karimov, F. Islomov, A. Avlokulov, Accounting, 1, 93 (2004)

6. B. Ruzmetov, O. Bekturdiev, K. Yuldosheva, S. Matkarimov, Cost Calculation, 230 (2006)

7. B. Khasanov, A. Khashimov, Management Calculus, 312 (2013)

8. S. N. Tashnazarov, Managing Calculation, 260 (2010)

9. L. V. Shalaeva, Cost Accounting and Calculating the Cost of Production in Crop Production, 2, 258 (2008)

10. N. Noskova, Cost Accounting, 1, 129 (2009)

11. R. Dusmuratov, B. Menglikulov, Statistics and Accounting in Agriculture, 7, 392 (2014)

12. V. E. Kerimov, Cost Calculations, 246 (2005) (in Russian)

13. A. Makhkambaev, F. Abduvakhidov, D. Satyvaldieva, E. Shodiev, Costing, 208 (2012)

14. R. Dusmuratov, Fundamentals of Accounting, 7(43), 476-481 (2013)

15. R. Alborov, Management Accounting, 1, 224 (2005)

16. L. I. Khoruzhiy, Economy of Agricultural and Processing Enterprises, 1, 59-62 (2012)

17. YU. Belkin, Concise Dictionary of Economics, 399 (1997)

18. A. V. Zonova, Accounting and Analysis, 2(12), 512-519 (2009)

19. V. A. Pipko, Accounting in Agriculture, 6, 39-45 (2009)

20. G. R. Kontsevoy, Development of Management Accounting and Control of Biological and Total Costs in Agriculture, DSc thesis, 201(2010) (in Russian)

21. G. Kontsevoy, Economy of Agricultural and Processing Enterprises, 1, 26-29 (2015)

22. L. I. Khoruzhiy, Izhevsk State Agricultural Academy Bulletin, 45, 56-60 (2017) (in Russian)

23. L. I. Khoruzhiy, Accounting in Agriculture, 3, 6-20 (2017)

24. O. Goryunova, Agricultural Sciences, 2, 12-14 (2009) 